\title{
New wine-growing regions of Brazil and their importance in the evolution of Brazilian wine
}

\author{
Douglas André Wurz ${ }^{\text {a }}$, Betina Pereira de Bem, Ricardo Allebrandt, Bruno Bonin, Luiz Gabriel Dalmolin, Adrielen Tamiris \\ Canossa, Leo Rufato, and Aike Anneliese Kretzschmar
}

Santa Catarina State University (UDESC), College of Agriculture and Life Science, Av. Luiz de Camões, 2090, CEP 88520-000, Lages, SC, Brazil

\begin{abstract}
The objective of this work is to characterize the new Brazilian wine regions, describing their edaphoclimatic and productive characteristics, wine types, and their importance in the evolution of Brazilian wine industry. The Campanha Gaúcha is characterized by flat lands, presents a high number of hours of light, and dry summers, guaranteeing a complete maturation of the grapes. Including the locations The Southeastern Region of Rio Grande do Sul presents pronounced ripples, located in altitudes between 400 and $600 \mathrm{~m}$, presenting dry and sunny summers with cold nights, stony soil; Merlot and Cabernet Franc are the outstanding varieties. In the northern plateau of Rio Grande do Sul, at $1000 \mathrm{~m}$ a.s.l., the region of Campos de Cima da Serra has a characteristic high solar incidence, and due to the low nocturnal temperatures. The Altitude Region of Santa Catarina State presents similar characteristics to those found in the Campos de Cima da Serra, with vineyards located between 900 and $1400 \mathrm{~m}$, the slow maturation promotes the preservation of acidity and high levels of aromatic compounds, which confer freshness and typical white wines, respectively, especially those made from the Sauvignon Blanc. Located at medium elevations of 900 to $1100 \mathrm{~m}$, the region of Greater Curitiba with hot days and mild nights, stands out for the production of varieties of short to medium cycle, because it presents humid summers favoring the occurrence of diseases fungal infections. The South of Minas Gerais State presents mean altitudes of 800 and $1000 \mathrm{~m}$, in which the technique of double pruning was adopted, leading the grapes maturation to occur during the winter, when a dry season with mild temperatures is found, making it an ideal place to produce high quality Syrah wines. In São Paulo State, altitudes between 1,000 and 1,300 m a.s.l. are found, where cool nights and excellent sunshine during the day provide thermal amplitude of $10^{\circ} \mathrm{C}$ at the time of harvest. Add to this a dry, well-drained and granitic soil, especially for growing Syrah and Viogner. The São Francisco River Valley presents flat lands, at an altitude of 400 meters. Located outside the suitable range for growing grapes, this semi-arid region presents low rainfall (less than $500 \mathrm{~mm}$ a year) and strong insolation. Its permeable clay soils have proven to be suitable for the acclimatization of grapevines such as Moscatel, Cabernet Sauvignon and Syrah.
\end{abstract}

\section{Introduction}

The first vines cultivated in Brazil were of European origin and emerged with the arrival of Portuguese colonizers (1532). In the mid-nineteenth century, Italian immigrants introduced the "Isabel" American grape variety, culminating in the rapid replacement of vine varieties of European varieties, becoming the basis for the development of commercial winemaking in the states of Rio Grande do Sul and São Paulo. From the beginning of the twentieth century, São Paulo viticulture replaced the cultivars of the variety "Isabel" by "Niagara Branca" and "Seibel II". In the same period, with government incentives, Rio Grande do Sul intensified the planting of vine varieties [1].

Since 1875 , with the arrival of the Italian immigrants, the winemaking activity is present in the Serra Gaúcha, and over the years, production has been improving and reaching quite satisfactory levels of development, transforming the place into a national wine-growing pole [2].

a e-mail: douglaswurz@hotmail.com
Until the end of the 1950s, Brazilian commercial viticulture was restricted to the three southern states and the eastern regions of São Paulo and southern Minas Gerais. From there, there was a great enlargement of the wine-growing frontier. In traditional regions, production systems have been modified over the years, depending on market opportunities and requirements [3].

The 1990s presented a scenario of a restructuring and/or reconversion of the profile of the wine industry in the State of Rio Grande do Sul. The need for the wine industry to face the intensification of competition with foreign wines and the progressive drop in wine consumption worldwide have led industry leaders to devise strategies that could redefine the organization of viticulture in South-Rio Grande. The 90's can be considered the first great evolution of Brazilian wine.

However, despite the existence of several improvements that facilitate the development of the wine production process, there is a locational movement in Brazilian winemaking: the growth of wine production outside the traditional region (Serra Gaúcha) [2]. This locational movement of viticulture allowed the discovery 
of new terroirs in Brazil, allowing the elaboration and commercialization of differentiated products. Therefore, it is a determining factor for the evolution of Brazilian winemaking.

In this context, the objective of this work is to characterize the new Brazilian wine-growing regions, describing their edaphoclimatic and productive characteristics, wine types, and their importance in the evolution of Brazilian wine.

\section{Materials and methods}

The study was developed through a qualitative research, from a descriptive perspective.

For the development of the work scientific works and national publications were compiled referring to the evolution of Brazilian wine, as well as the regions that produce fine wines in Brazil. Consultations were made to the bibliographic collection of the State University of Santa Catarina, as well as consultations in indexed periodicals, with the objective of exploring the following contents: Brazilian winemaking, Brazilian wine evolution, wine producing regions in Brazil, Brazilian winemaking map, campanha gaúcha, Southeastern Region, Campos de Cima da Serra, Altitude Regions in Santa Catarina State, Region of Curitiba in Paraná State, State of São Paulo; South Region of Minas Gerais State and the São Francisco Valley in Pernambuco State.

The data were also collected in institutions responsible for the elaboration and dissemination of data related to winemaking in Brazil, such as: Brazilian Wine Institute, IBRAVIN, Embrapa Uva e Vinho, Ministry of Agriculture and Brazilian Union of Winemaking, UVIBRA.

From the data cataloged, it was possible to elaborate tables and figures that demonstrate the evolution of Brazilian wine, as well as to characterize the new Brazilian wine regions, describing their edaphoclimatic and productive characteristics, wine types, and their importance in the evolution of Brazilian wine.

\section{Results and discussion}

The Brazilian viticulture presents great diversity. The culture is spread from Rio Grande do Sul, at $31^{\circ} \mathrm{S}$ latitude, to Rio Grande do Norte and Ceará, at $05^{\circ} \mathrm{S}$ latitude. The variation of altitude is also great, with considerable environmental diversity between production zones, including temperate, subtropical and tropical regions [3].

In the last years the grapevine cultivation in the West Frontier of the State of Rio Grande do Sul has been emphasizing among the producers as an alternative of cultivation, driven by the ease of mechanization, due to its flat relief and mainly by the edaphoclimatic conditions that allow the production of Grapes and the elaboration of fine wines with unique characteristics [4]. The long days, with a great period of luminosity for the plants, and the great temperature variation between the day and the night benefit the cultivation of the vines. Favorable conditions are complemented by soil, rich in granite and limestone.

Including the towns of Pinheiro Machado and Encruzilhada do Sul, in the region of Serra do Sudeste, vitiviniculture gained economic importance, more recently, from investments made by wineries located in the
Table 1. Wine-growing regions and their edaphoclimatic characteristics and altitude above sea level.

\begin{tabular}{|c|c|c|}
\hline Wine-growing & $\begin{array}{l}\text { Altitude } \\
\text { (m) }\end{array}$ & Characteristics \\
\hline Campanha Gaúcha & 150 & $\begin{array}{l}\text { High number of hours of } \\
\text { light, and dry summers. }\end{array}$ \\
\hline Southeastern Region & $400-600$ & $\begin{array}{l}\text { Dry and sunny summers } \\
\text { with cold nights, stony } \\
\text { ground }\end{array}$ \\
\hline $\begin{array}{l}\text { Campos de Cima da } \\
\text { Serra }\end{array}$ & $900-1300$ & $\begin{array}{l}\text { High solar incidence, } \\
\text { longer vegetative cycle, } \\
\text { high aromatic intensity } \\
\text { and content of phenolic } \\
\text { compounds }\end{array}$ \\
\hline Altitude Wines & $900-1400$ & $\begin{array}{l}\text { Slow ripening, preser- } \\
\text { vation of acidity and } \\
\text { high levels of aromatic } \\
\text { compounds }\end{array}$ \\
\hline $\begin{array}{l}\text { Metropolitan Region } \\
\text { of Curitiba }\end{array}$ & $900-1100$ & $\begin{array}{l}\text { Hot days and mild } \\
\text { nights, stands out for the } \\
\text { production of short to } \\
\text { medium cycle varieties }\end{array}$ \\
\hline $\begin{array}{l}\text { South Region of } \\
\text { Minas Gerais }\end{array}$ & $800-1000$ & $\begin{array}{l}\text { It was adopted the dou- } \\
\text { ble pruning, that causes } \\
\text { that the cycle of the } \\
\text { grapevine changes, with } \\
\text { the maturation happen- } \\
\text { ing in the winter }\end{array}$ \\
\hline São Paulo State & 1000-1300 & $\begin{array}{l}\text { Fresh nights and excel- } \\
\text { lent sunshine that pro- } \\
\text { vide a thermal amplitude } \\
\text { of } 10^{\circ} \mathrm{C} \text { at harvest time }\end{array}$ \\
\hline San Francisco Valley & 400 & $\begin{array}{l}\text { Low rainfall (less than } \\
500 \mathrm{~mm} \text { ) and strong sun- } \\
\text { shine. Pervious sandy- } \\
\text { loam soils }\end{array}$ \\
\hline
\end{tabular}

Serra Gaúcha. Vitis vinifera grape varieties are cultivated, predominantly of red grapes. The productivity of the vineyards in the region is between 8 and $12 \mathrm{t} / \mathrm{ha}$, depending on the crop and climatic conditions of the crop [5]. The Serra do Sudeste is a region formed by successive undulations in the terrain, with altitudes varying between 400 and 500 meters. Even though it has no tradition in winemaking activity, it is being reported that this region has been considered as one of the newest terroirs in Rio Grande do Sul state. In the year 2014, the Serra do Sudeste region produced 4.76 million kilos of grapes. The hybrid and American grapes totaled 1.84 million kilos and the grapes 2.92 million kilos, confirming the region's specialization for grapes destined to produce fine wines $[6,7]$. The mountain range has proven suitable in the cultivation of noble grapes, such as Cabernet Franc and Merlot, white such as Sauvignon Blanc and Malvasia. The current harvest of the region produces enough to produce 500 thousand bottles of red and white, vinified for the time being in facilities of the Serra Gaúcha. It is mentioned as one of the most promising Brazilian producing areas. Curiously, the Serra do Sudeste is home to very few canteens. Most of the grapes are transported, usually at night, to other regions of Rio Grande do Sul, where it is vinified. However, with the growth of its importance in the national oenological scenario and with the emergence 
of local enterprises focused on grape production, this situation must change in the near future.

The region of Campos de Cima da Serra is located on the border with the state of Santa Catarina, is formed by a set of slopes and huge walls whose altitude varies from 900 to 1,100 meters. This region has a small area that stands out due to the wines and sparkling wines from municipalities such as Bom Jesus, Jaquirana, São Francisco de Paula, Vacaria and Many Capões. In 2014 the region produced 7.19 million kilos of grapes [6,7]. For a long time, the region of Campos de Cima de Serra was in the shadow of the Serra Gaúcha. The predominance of the cultivation of hybrid varieties and the cold and windy climate were seen as obstacles to the development of large vineyards. Today, however, the scenario is the opposite. The low temperature and the constant incidence of the wind have been transformed into differentials, because they allow a longer maturation and conditions for the grapes to present excellent sanity. The initiatives of entrepreneurs who ventured to elaborate wines in the region were rewarded with great labels, now nationally known for their quality. The soil presents characteristics favorable to the cultivation of the vine, such as good structure, effective depth above $1.50 \mathrm{~m}$, very good drainage and low natural fertility.

The vineyard of Santa Catarina has recently stood out in front of the other fine wines producers in Brazil. Grapes produced in regions of altitude above $900 \mathrm{~m}$ have their own characteristics and are distinct from those cultivated in other areas of the country, as well as phenolic maturation adequate to the elaboration of wines $[8,9]$. The climatic potential of the high altitude regions for the production of vinifera grapes (Vitis vinifera L.) in Santa Catarina, has been proven through several surveys. These conditions provide a differentiated climate in relation to the other wine regions of Brazil, interfering mainly in the phenological cycle. Due to the milder air temperatures in these regions, the vegetative and reproductive cycle of the grapevine is more extensive, resulting in slower ripening of the grapes for the production of fine quality wines $[10,11]$. In addition, it causes maturation in less frequent months (April and May) and amount of rainfall, providing grapes with greater sanity and oenological quality.

The elevation region of the state of São Paulo is characterized by altitudes between $1,000 \mathrm{~m}$ and $1,300 \mathrm{~m}$, cool nights and excellent sunshine during the day provide a thermal amplitude between $10^{\circ} \mathrm{C}$ and $12^{\circ} \mathrm{C}$ at the time of harvest, similar to that of large European regions. Add to this a dry soil - with good drainage - and granitic, which is especially suitable for grapes destined to the production of high quality wines. The result is a great terroir.

In Minas Gerais state, viticulture focused on the elaboration of wines is concentrated in the southern region of the State, mainly in the municipalities of Caldas and Andradas [12]. The cultivation of grapes for the elaboration of fine wines in Minas Gerais Is a recent practice.The Technological Center EPAMIG Uva e Vinho has been active in the search for new farming regions in the State of Minas Gerais guided by the principles that fine wines are produced in regions where the grape harvest is made in dry periods and has $\left(10^{\circ} \mathrm{C}\right)$, above which the vine can grow almost all year round, and thus its cycle is defined as a function of the date of pruning [13]. The first projects to explore these principles were installed in the year 2001 in Três Corações, and the results showed that Syrah grapevines, pruned in January, show a new cycle of normal vegetation and production, with rates of sprouting, fertility Of the buds, maturation and sanity markedly higher than those observed for this same cultivar during the summer $[12,14]$. The great virtue of inverting the grapevine cycle is that during the winter period, in the South of Minas, the days are dry and hot and the nights cold, with great daily thermal amplitude that helps in the slow process of ripening of the grape, which Leads to the excellent fixation of the aromas and favors the accumulation of polyphenols, which dictate the color intensity of the fruit and the production of tannin, essential substance for a good structure and wine longevity. In addition, avoiding the rainy season increases the possibility of a complete phenolic maturity of the grapes that reaches an optimal sugar concentration.

In the Northeast of Brazil, the São Francisco Valley is located between the $8-9^{\circ}$ parallels of the Southern Hemisphere, is a semi-arid tropical climate region, with edaphoclimatic characteristics that make it possible to stagger the production of grapes for wines throughout the year. A vine plant can produce two harvests per year due to high temperatures, high insolation rates and abundant water available for irrigation from the São Francisco River. This fact allows investments in physical structure to be smaller than those carried out in temperate regions, where the harvest of grapes is concentrated in three or four months of the year, depending on the cycle of each variety [15]. Depending on the month of harvest and preparation, the wines present great variations in composition, quality and typicity, mainly due to intra-annual climatic variability [16]. The main varieties used for the production of red wines in the region of the Valley of the Submédio San Francisco are syrah, tempranillo, national touriga, cabernet sauvignon, alicante bouschet, ruby cabernet and petit verdot, and syrah represents about $65 \%$ of red wines. In the case of whites, the grapes used are chenin blanc, sauvignon blanc, muscato canelli and viognier, and chenin represents about $60 \%$ of the still white wines $[17,18]$.

\section{Conclusion}

Along the years, the Brazilian wine map has changed, with the beginning of the production of grapes in non-traditional regions, This diversity presents itself as a differential in the quality of the elaborated products, contributing to the evolution of the Brazilian wine.

\section{References}

[1] R.V. Botelho, J.P. Pires. Viticultura como opção de desenvolvimento para os Campos gerais. In: Anais Encontro de Fruticultura dos Campos Gerais 1, 40-54 (2009)

[2] L.S. Kummel, M.A.D. Moraes, P.V. Marques. Dinâmica locacional da vitivinicultura no Rio Grande do Sul e no Vale do São Francisco. Revista de Política Agrícola 18, 36-49 (2009)

[3] U.A. Camargo, J. Tonietto, A. Hoffmann. Progresso na Viticultura Brasileira. Revista Brasileira de Fruticultura 33, 144-149 (2011)

[4] G.F. Brixner, C.R. Martins, U. Amaral, L.M. Kopp, D.B. Oliveira. Caracterização fenológica e exigência térmica de videiras Vitis vinífera cultivadas no 
município de Uruguaiana, na região da fronteira oeste - RS. Revista da FZVA 17, 221-233 (2010)

[5] J.F. Protas, U.A. Camargo. Vitivinicultura brasileira: panorama setorial (SEBRAE, Brasília, 2010)

[6] M. Copello. As regiões produtoras do Brasil. Revista Anuário Vinho do Brasil, São Paulo (2015)

[7] IBRAVIN - Instituto Brasileiro do Vinho Dados estatísticos - Produção de uvas no Brasil. (IBRAVIN, Bento Gonçalves, 2015)

[8] L.D. Falcão, E.S. Chaves, V.M. Burin, A.P. Falcão, V. Bonin, M.T. Bordigon-Luiz. Maturity of Cabernet Sauvignon verries from grapevines grown with two differente training systems ina a new grape growning region in Brazil. Ciencia e Investigácion Agraria 35, 271-282 (2008)

[9] L.C. Silva, L. Rufato, A.A. Kretzschmar, J.L. Marcon Filho. Raleio de cachos em vinhedos de altitude e qualidade do vinho da cultivar Syrag. Pesquisa Agropecuária Brasileira 44, 148-154 (2009)

[10] E.F. Gris, V.M. Burin, E. Brighenti, H.J. Vieira, M. Bordigon-Luiz. Phenology and ripening of Vitis vinifera grape varieties in São Joaquim, southern Brazil: a new wine growing region. Ciência e Investigácion Agraria 37, 61-75 (2010)

[11] L.I. Malinovski, L.J. Welter, A.F. Brighenti, H.J. Vieira, M.P. Guerra, A.L. Da Silva. Highlands of Santa Catarina/Brazil: a region with high potencial for wine production. Acta Horticulturae 931, 433-440 (2012)
[12] A.C. Favero, D.A. Amorim, R.V. Mota, A.M. Soares, M.A. Regina. Viabilidade de produção da videira Surah em ciclo de outono inverno na região Sul de Minas Gerais. Revista Brasileira de Fruticultura 30, 685-690 (2008)

[13] M.A. Regina, D.A. Amorim, A.C. Favero, R.V. Mota, D.J. Rodrigues. Novos polos vitícola para a produção de vinhos finos em Minas gerais. Informe Agropecuário 27, 111-118 (2006)

[14] D.A. Amorim, A.C. Favero, M.A. Regina. Produção extemporânea da videira cv. Syrah nas condições do sul de Minas Gerais. Revista Brasileira de Fruticultura 27, 327-331 (2005)

[15] G.E. Pereira. Os vinhos tropicais em desenvolvimento no Nordeste do Brasil. Com Ciência 149, 1-3 (2013)

[16] O. Tonietto, A.H. Teixeira. Zonage climatique des périodes viticoles de production l'année em zonage tropicale: application de la methodologie du Systéne CCM Géoviticole. In: Joint International Conference on Viticultural Zoning, Cape Town, South Africa. S.I.: s.n., 193-201 (2004)

[17] G.E. Pereira, A.J.B. Araújo, J. Santos, R. Vanderlinde, L. Lima. Chemical and aromatic characteristics of Brazilian tropical wines. Acta Horticulturae 910, 135-140 (2011)

[18] U.A. Camargo, G.E. Pereira, C.C. Guerra. Wine grape cultivars adaptation and selection for tropical wines. Acta Horticulturae 191, 121-129 (2011) 